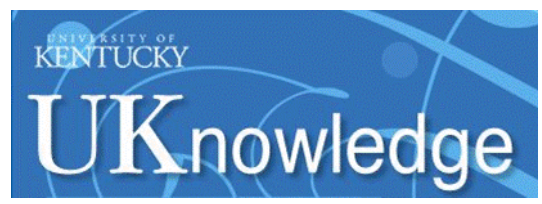

University of Kentucky

UKnowledge

$12-2017$

\title{
Sustained Sensitizing Effects of Tumor Necrosis Factor Alpha on Sensory Nerves in Lung and Airways
}

\author{
Ruei-Lung Lin \\ University of Kentucky, rueilung.lin@uky.edu \\ Qihai Gu \\ Mercer University \\ Mehdi Khosravi \\ University of Kentucky, mehdi.khosravi@uky.edu \\ Lu-Yuan Lee \\ University of Kentucky, lylee@uky.edu
}

Follow this and additional works at: https://uknowledge.uky.edu/physiology_facpub

Part of the Pharmacology Commons, Physiology Commons, Pulmonology Commons, and the Therapeutics Commons

Right click to open a feedback form in a new tab to let us know how this document benefits you.

\section{Repository Citation}

Lin, Ruei-Lung; Gu, Qihai; Khosravi, Mehdi; and Lee, Lu-Yuan, "Sustained Sensitizing Effects of Tumor Necrosis Factor Alpha on Sensory Nerves in Lung and Airways" (2017). Physiology Faculty Publications. 139.

https://uknowledge.uky.edu/physiology_facpub/139

This Article is brought to you for free and open access by the Physiology at UKnowledge. It has been accepted for inclusion in Physiology Faculty Publications by an authorized administrator of UKnowledge. For more information, please contact UKnowledge@lsv.uky.edu. 


\section{Sustained Sensitizing Effects of Tumor Necrosis Factor Alpha on Sensory Nerves in Lung and Airways}

Digital Object Identifier (DOI)

https://doi.org/10.1016/j.pupt.2017.06.001

Notes/Citation Information

Published in Pulmonary Pharmacology \& Therapeutics, v. 47, p. 29-37.

(C) 2017 Elsevier Ltd. All rights reserved.

This manuscript version is made available under the CC-BY-NC-ND 4.0 license

https://creativecommons.org/licenses/by-nc-nd/4.0/.

The document available for download is the author's post-peer-review final draft of the article. 


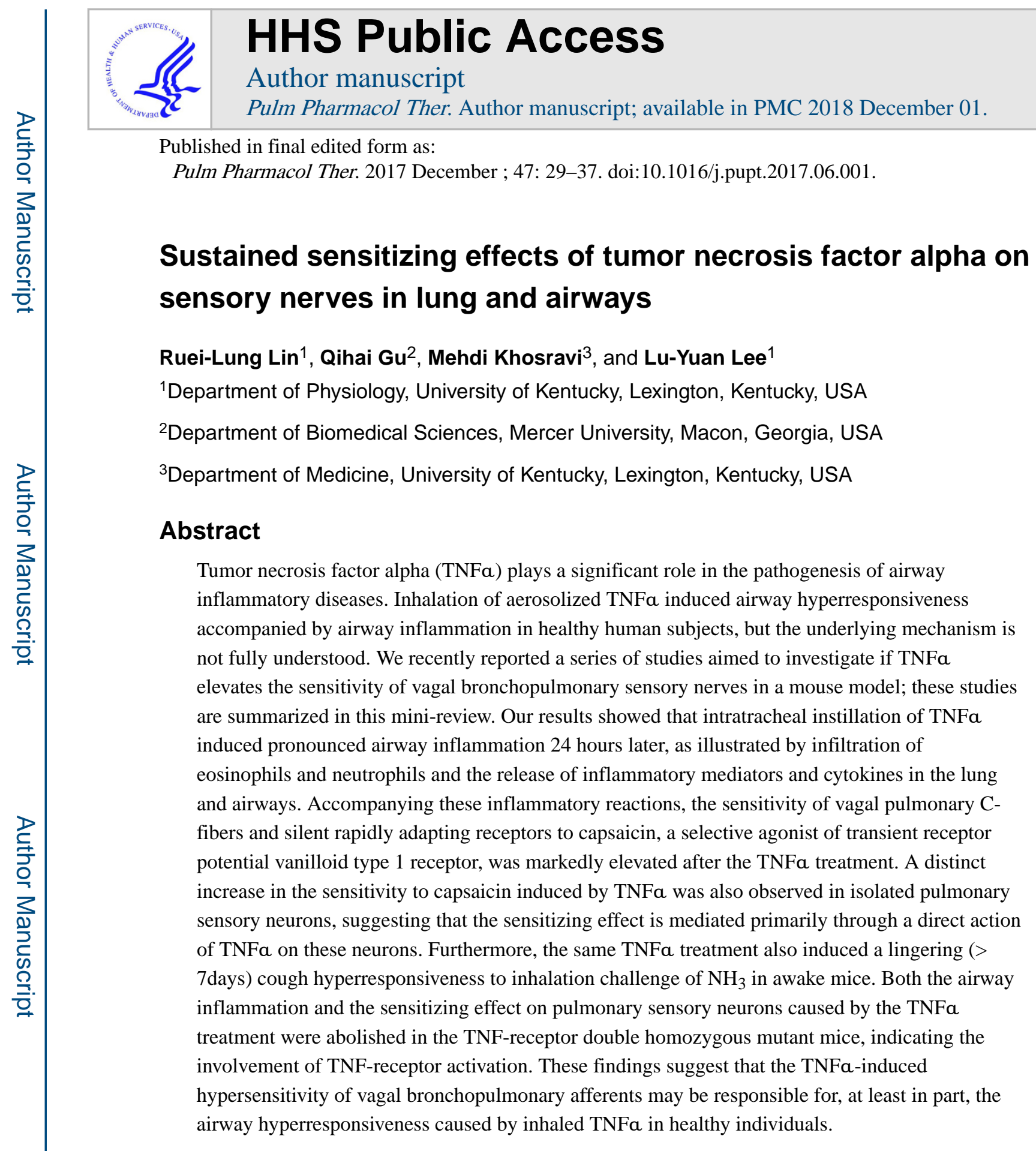

\section{Keywords}

asthma; airway inflammation; TRPV1; cough; mouse

\footnotetext{
Corresponding author: Lu-Yuan Lee, Ph.D., Department of Physiology, University of Kentucky Medical Center, Lexington, Kentucky 40536-0298, USA, Telephone: 859-323-6339, lylee@uky.edu.

Publisher's Disclaimer: This is a PDF file of an unedited manuscript that has been accepted for publication. As a service to our customers we are providing this early version of the manuscript. The manuscript will undergo copyediting, typesetting, and review of the resulting proof before it is published in its final citable form. Please note that during the production process errors may be discovered which could affect the content, and all legal disclaimers that apply to the journal pertain.
} 


\section{Introduction}

An important role of tumor necrosis factor alpha (TNFa), a pro-inflammatory cytokine, in the pathogenesis of airway inflammatory diseases such as allergic asthma has been extensively documented [1-5]. TNFa was detected in bronchoalveolar lavage fluid, exhaled breath condensate and sputum of asthmatic patients during acute exacerbation or after antigen inhalation challenge in these patients [6,7]. TNFa is released from a variety of cell types in the airways, such as mast cells and macrophages, via the immunoglobulin Edependent mechanism $[2,5,8,9]$. Once released, TNFa can exert multiple effects on a number of effector cells and induce the inflammatory reaction in the airways. Inhalation of aerosolized TNFa induced bronchial hyperresponsiveness accompanied by airway inflammation in healthy human subjects [10], but the underlying mechanism was not fully understood. One of the prominent pathophysiological features of inflammation-induced bronchial hyperresponsiveness is a heightened sensitivity of airway sensory nerves [11,12].

Previous investigators have repeatedly reported that TNFa induced a potent sensitizing effect on dorsal root ganglion (DRG) and trigeminal ganglion nociceptive neurons, leading to the development of lingering inflammatory pain in various somatic tissues [13-16]. This hyperalgesic effect was mediated through an action on the TNF receptors, TNFR1 and TNFR2, located on the cell surface, which resulted in an increase in the sensitivity and/or expression of transient receptor potential vanilloid type 1 (TRPV1) receptors expressed in these nociceptive neurons [3]. For example, in isolated DRG neurons, pretreatment with $\mathrm{TNFa}$ for a short-duration (60 s) immediately and reversibly increased the current amplitude evoked by activation of TRPV1 receptors, and this rapid and transient sensitizing effect of TNFa was attenuated by deletion of the TNFR2 gene [17]. On the other hand, exposure of DRG neurons to TNFa for a longer duration (48 hours) induced a pronounced increase in the proportion of DRG neurones expressing TRPV1 receptor-like immunoreactivity [18]. Interestingly, the TNFa-induced TRPV1 expression was clearly increased in the mediumand large-size neurons that normally do not exhibit TRPV1 sensitivity; and this effect of TNFa was absent in the DRG neurons isolated from mice lacking TNFR1 [18].

The $\mathrm{C}$-fiber sensory nerves are the dominant subtype of vagal afferents innervating the entire respiratory tract in various mammalian species including mice [19-21]. Increasing evidence suggests that activation of these bronchopulmonary C-fiber afferents is responsible for the manifestation of various symptoms in the airway inflammatory diseases [11,12]. An abundant expression of TRPV1 in the neuronal soma and sensory terminals is a reliable and prominent biomarker of these C-fiber afferents [22,23]. More importantly, recent studies have shown that chronic airway inflammation upregulated the sensitivity and expression of TRPV1 in these sensory nerves innervating the airways and lungs [24,25].

In the light of these previous findings, we recently carried out a series of studies aimed to investigate if airway delivery of TNFa induced airway inflammation and elevated the TRPV1 sensitivity of bronchopulmonary sensory nerves; and if so, whether the sensitizing effect of TNFa was mediated through its action on TNFRs. Mouse was chosen as the animal species for these studies so that the involvement of TNFRs could be evaluated in TNFreceptor double homozygous mutant mice $\left(\mathrm{TNF}^{-/}\right)$. Experimental methods, protocols and 
results of these studies have been reported in details in our recent publications [26-28], and a collected summary of this series of studies is presented in this mini-review.

\section{Airway inflammation induced by TNFa}

$\mathrm{TNFa}$ released from mast cells, macrophages and other inflammatory cells can trigger diverse and potent inflammatory responses in the airways. Activation of TNFRs by TNFa can cause a chemotactic action, upregulate the leukocyte-endothelial cell adhesive molecules E-selectin and vascular cell adhesion molecule-1, which in turn can enhance the production of Th2 cytokines and cause infiltration and degranulation of these inflammatory cells such as neutrophils and eosinophils in the airways $[5,10,29,30]$. These diverse actions of TNFa can further enhance the release of various pro-inflammatory/chemotactic mediators [5,29]. We carried out this study to determine whether airway inflammation is induced by $\mathrm{TNFa}$ treatment in our mouse model, and if so, if this effect is mediated through the action of TNFa on TNFRs. The experiments were carried out in two groups of young male mice: wild-type (WT; B6129SF2/J) and $\mathrm{TNF}^{-/-}$mice (129S-Tnfrsf1a ${ }^{\text {tm1Imx }}$ Tnfrsf1 $1 b^{\text {tm1Imx/J) in }}$ which both types of TNF receptors, TNFR1 and TNFR2, were mutated.

The animal preparation and experimental methods were described in details by Lin et al [27]. Briefly, after mice were anesthetized by isoflurane inhalation, a small $(\sim 0.5 \mathrm{~cm})$ midline incision was made on the ventral neck skin to expose the trachea. Under sterile condition, TNFa solution $(10 \mu \mathrm{g} / \mathrm{ml} ; 0.03 \mathrm{ml}$ ) and its vehicle (Veh; phosphate buffered saline, $0.03 \mathrm{ml}$ ) were instilled into the trachea via a needle (28-gauge) in treated (TNFa) and control (Veh) mice, respectively; the incision was then closed. Twenty-four hours (unless noted otherwise) later, bronchoalveolar lavage fluid (BALF) was obtained for measurements of inflammatory cells and mediators from five groups of mice: 1) Naïve group (WT mice receiving no surgery or treatment); 2) Veh group (WT mice treated with Veh); 3) \& 4): TNFa 1 and 7 days groups (WT mice 1 and 7 days after treatment with TNFa); and 5) $\mathrm{TNF}^{-/}+\mathrm{TNFa}$ group $\left(\mathrm{TNF}^{-/}\right.$-mice treated with $\left.\mathrm{TNFa}\right)$.

BALF samples were obtained from 5 mice in each group for the differential cell count, except $n=7$ in the TNFa (7 days) group. Results showed that the total number of leukocyte cells was significantly higher in the WT mice 1 day after a treatment with TNFa than that in each of the other four groups of mice. No significant difference was found between these four other groups [27]. More strikingly, the percentages of eosinophils and neutrophils in the $\mathrm{TNFa}$ ( 1 day) group were $>15$ folds higher than that in naïve, Veh, TNFa ( 7 days), and $\mathrm{TNF}^{-1-}+\mathrm{TNFa}$ groups, and no significant difference was found in either eosinophils or neutrophils between these four other groups [27].

Several inflammatory mediators and cytokines were selected in this study for measurements because their possible changes after the TNFa treatment were suggested in previous reports [2,5,30,31]. BALF samples were collected for ELISA from separate groups of mice, and the results showed that the TNFa treatment significantly elevated the levels of leukotriene (LT) B4, LTC4/D4/E4, histamine, thromboxane $\mathrm{B}_{2}$ and interleukin $1 \beta$ in the BALF of WT mice, compared to that in the naïve, Veh and $\mathrm{TNF}^{-/-}$groups, and there was no significant difference in these inflammatory mediators and cytokine between these three other groups 
(Fig. 1). However, we did not find any significant difference in the level of $\mathrm{PGE}_{2}$ and IL-13 in BALF among all four groups. These measurements were not made in the TNFa (7 days) group. The total number of mice used in these groups varied: $\mathrm{n}=10,15,15$ and 5 in naïve, Veh, TNFa, and $\mathrm{TNF}^{-/}+\mathrm{TNFa}$ groups, respectively. Due to the minimum BALF sample volumes required for various ELISA tests, certain assays (e.g., LTB $_{4}$ and IL-1 $\beta$ ) were not performed in all 4 groups (Fig. 1). Pentraxin 3 (PTX3), a member of the pentraxin superfamily of proteins that are involved in acute immunological responses to tissue injury [32], was probably released in response to the surgical wound and needle puncture on the trachea during the intra-tracheal instillation of TNFa. There was no difference in the level of PTX3 between TNFa- and Veh-treated mice.

Some of these autacoids such as histamine, leukotrienes and thromboxanes [27] are known to exert potent stimulatory and/or sensitizing effects on vagal bronchopulmonary C-fiber afferents $[11,20]$.

\section{Hypersensitivity of vagal bronchopulmonary afferents to capsaicin induced by TNFa}

To determine if the $\mathrm{TNFa}$-induced inflammation can lead to the development of airway hypersensitivity, we studied the effect of TNFa treatment on vagal pulmonary afferents in young C57BL6/J mice [26]. TNFa and Veh were administered as described earlier. One to two days later, single-unit activities of vagal afferents were recorded from the sectioned right cervical vagus nerve in anesthetized, open-chest mice. Responses to both chemical (capsaicin) and mechanical (lung inflation and deflation) stimulations were studied in all three major types of vagal bronchopulmonary afferents that were identified based upon conventional criteria for classifications [11]: C-fibers, rapidly adapting receptors (RARs), and slowly adapting receptors (SARs). Action potentials generated from C-fiber endings are conducted in small-diameter non-myelinated afferent fibers, whereas those from RARs and SARs are carried in rapid-conducting large-diameter myelinated fibers. The general location of each receptor in the lung and airways was identified at the end of experiment.

An intravenous bolus injection of capsaicin (Cap, a selective agonist of TRPV1 [33,34]) triggered an abrupt (latency $<1 \mathrm{~s}$ ) and short-duration (3-5 s) of discharge in pulmonary Cfibers accompanied by bradycardia and hypotension (e.g., Fig. 2). The pulmonary C-fiber responses to both low $(0.5 \mu \mathrm{g} / \mathrm{kg})$ and high doses $(1.0 \mu \mathrm{g} / \mathrm{kg})$ of Cap were significantly higher in TNFa-treated mice than that in Veh-treated mice (Fig. 2). Pulmonary C-fibers were relatively insensitive to lung inflation, and the TNFa treatment did not increase the responses of pulmonary C-fibers to lung inflation.

In both Veh- and TNFa-treated mice, a large percentage of the RARs exhibited distinct phasic baseline activity that was synchronous with either expiratory or inspiratory phase of respiratory cycles. The remaining RARs had no detectable or very little respiratory-related baseline activity (e.g., Fig. 3). These two types of RARs were categorized as phasic RARs and silent RARs in this study. All of the SARs tested in this study exhibited distinct phasic baseline activity that reached a peak during either inspiratory or expiratory phase of the 
respiratory cycles; the latter was found only in a relatively smaller number in the mouse lung [26].

In Veh-treated mice, injections of Cap did not cause significant stimulatory effect on silent RARs (e.g., Fig. 3A). However, the responses of these silent RARs to Cap injections were elevated by $>10$ folds in TNFa-treated mice (Figs. 3B \& 3C). Furthermore, the number of silent RARs that were activated by Cap injections, judged by the criterion that the increase in fiber activity was $>1.0 \mathrm{imp} / \mathrm{s}$, was markedly higher in TNFa-treated mice: e.g., none of the 9 silent RARs tested were activated by the low dose of Cap $(0.5 \mu \mathrm{g} / \mathrm{kg})$ in the Veh group, whereas 6 of the 8 silent RARs were stimulated in the TNF group (Fig. 3D). In contrast, there was no significant difference in the responses of silent RARs to either lung inflation $(\mathrm{P}>0.05)$ or deflation $(\mathrm{P}>0.05)$ between Veh- and TNFa-treated mice (Figs. 3E \& 3F). In addition, the treatment with $\mathrm{TNFa}$ did not cause any potentiating effect on the responses to the same Cap injection, lung inflation and deflation in phasic RARs or SARs [26].

It is well recognized that the afferent activity generated by these C-fiber endings plays an important role in eliciting the pulmonary defense reflexes in both healthy and disease conditions $[11,20]$. Activation of these afferent endings by either inhaled chemical irritants or endogenous inflammatory mediators can generate respiratory sensations such as airway irritation and urge to cough [11]. In addition, it elicits powerful reflex responses including airway smooth muscle contraction, bronchial vasodilation and mucous hypersecretion mediated through the cholinergic reflex pathways [20,35]. Intense and/or sustained stimulation of these afferents causes "neurogenic inflammation" in the tracheobronchial tree: extravasation of macromolecules and inflammatory cell chemotaxis, which involves the local "axonal reflex" and release of several potent bioactive tachykinins from these sensory endings [36,37]. Thus, it seems logic to postulate that when the excitability of C-fiber afferents is enhanced by endogenous TNFa, these airway reflex responses to a given stimulus will be intensified.

After the TNFa treatment, a distinct sensitivity to Cap injection emerged in the silent RARs. This is an interesting finding because these receptors rarely exhibited any Cap sensitivity in control mice. However, very little information is available regarding the electrophysiological properties (e.g., conduction velocity, ion channels, etc.) and reflex functions of these silent RARs in mice. The firing behavior of these silent RARs exhibited certain features resembling the "high-threshold A $\delta$ vagal afferents" described by Yu and coworkers [38]; for example, they displayed a very mild sensitivity to Cap and other chemical stimulants of Cfibers (e.g., sulfur dioxide; data not shown). Based upon our observations in a follow-up cough study (described later), it is also possible that some of these RARs are the cough receptors that have been identified in other species $[39,40]$.

\section{Hypersensitivity of isolated pulmonary sensory neurons induced by TNFa}

Because of the diverse actions of TNFa on a number of other target cells in the airways such as neutrophils, eosinophils and endothelial cells [5], it was impossible to determine if the sensitizing effect is mediated through a direct action of TNFa on these neurons in a wholeanimal preparation. Therefore, this in-vitro study was carried out to determine the direct 
effect of TNFa in isolated mouse pulmonary sensory neurons [26], using the $\mathrm{Ca}^{2+}$ imaging technique [41].

Pulmonary sensory neurons were isolated and cultured from the jugular-nodose ganglia complex in mice [21], and identified by retrograde labeling with DiI, a fluorescent dye, as previously described [42]. The changes in the intracellular $\mathrm{Ca}^{2+}$ concentration, $\left[\mathrm{Ca}^{2+}\right]_{\mathrm{i}}$, in response to three concentrations of Cap $(30,100$ and $300 \mathrm{nM})$ were measured in these neurons by the ratiometric method as described in our previous report [43].

Two matching dishes of pulmonary jugular-nodose ganglia neurons isolated and cultured from the same mouse were incubated with vehicle (Veh group) and $50 \mathrm{ng} / \mathrm{ml}$ of TNFa (TNF group) in culture medium for $24 \mathrm{~h}$. In the WT neurons incubated with TNFa, Cap challenge evoked a rapid and transient increase in the $\left[\mathrm{Ca}^{2+}\right]_{\mathrm{i}}$ in a concentration-dependent manner; this Cap-evoked increase in $\left.\mathrm{Ca}^{2+}\right]_{i}$ was significantly greater than that incubated with Veh, particularly at the higher concentrations of Cap (100 nM \& $300 \mathrm{nM}$; Fig. 4). In another study series, the Cap-evoked response was markedly attenuated in the $\mathrm{TNF}^{-/-}$neurons when the responses of $\left[\mathrm{Ca}^{2+}\right]_{\mathrm{i}}$ to increasing concentrations of Cap were compared between pulmonary sensory neurons isolated from WT mice and $\mathrm{TNF}^{-/-}$mice after both groups of neurons were incubated with TNFa $(50 \mathrm{ng} / \mathrm{ml})$ for $\sim 24 \mathrm{~h}$. These results suggest the involvement of TNFR receptors in the TNFa-induced hypersensitivity of these neurons.

In an immunohistochemical study, we have previously demonstrated the presence of both TNFR1 and TNFR2 on the cell membrane of rat vagal pulmonary sensory neurons [44]. Activation of these TNFRs by TNFa can trigger several signaling pathways that are involved in a wide range of immunological responses and inflammatory reactions [45-47]. $\mathrm{TNFa}$ is initially produced as a membrane-anchored precursor protein, and subsequently cleaved into free proteins, which form biologically active homotrimers and interact with these TNFRs. Activation of TNFR1 is known to activate nuclear factor-kappa B [48] and mitogen activated protein kinases (MAPK) pathways, including the extracellular signal regulated kinase (ERK) [49]. Indeed, activation of p38 MAPK pathway increased TRPV1 expression in peripheral nociceptor neurons in a transcription- independent manner [50]. Furthermore, it has been shown that incubation of DRG neurons with TNFa for 24-48 h significantly increased the proportion of DRG neurons expressing TRPV1 receptor-like immunoreactivity via TNFR1 and the ERK activation [18]. Interestingly, a recent study has demonstrated the co-localization of TNFR1 and TRPV1 in the same DRG neurons in rats [16].

Intracellular $\mathrm{Ca}^{2+}$ is an important signal transduction molecule and plays a significant role in the regulation of neuronal membrane excitability, synaptic activity and neurotransmitter release $[51,52]$. Transient changes in $\left[\mathrm{Ca}^{2+}\right]_{\mathrm{i}}$ are known to contribute to short- or long-term alterations in ion channels and gene expression, and can modulate the overall function of these afferents $[53,54]$. Because $\mathrm{Ca}^{2+}$ is one of the main ion species that is conducted through TRPV1, the TNFa-induced increase in $\mathrm{Ca}^{2+}$ transient in response to Cap may result from an increase in the TRPV1 expression and/or excitability. On the other hand, the TNFainduced sensitization of vagal C-fiber neurons should lead to a greater degree of subthreshold depolarization of the neuronal membrane and/or a larger number of action 
potentials in response to a given level of chemical stimulation, which may in turn generate a higher level of $\mathrm{Ca}^{2+}$ influx via voltage-dependent $\mathrm{Ca}^{2+}$ channels [26].

\section{Cough hyperresponsiveness induced by TNFa in awake mice}

One of the most important functions of these vagal bronchopulmonary afferents is to protect the lung and the rest of body against inhaled irritants and harmful gases in the environmental air. When the bronchopulmonary $\mathrm{C}$-fibers are activated by irritant gases inhaled into the respiratory tract, it can trigger vigorous airway reflex responses such as cough, bronchoconstriction and airway secretion; these reflex responses can expel and/or reduce the penetration of these harmful gases into deeper regions of the lung. Furthermore, a subset of RARs have been identified and characterized as cough receptors in other species by previous investigators; these receptors are located in the extrapulmonary airways and quiescent during eupneic breathing $[39,40]$. Based upon these background information, we hypothesized that the hypersensitivity of these afferents induced by TNFa elevated the cough responses to inhaled irritant gases in mice. We chose ammonia $\left(\mathrm{NH}_{3}\right)$ as the irritant gas to test this hypothesis because $\mathrm{NH}_{3}$ is generated by nature as part of the nitrogen cycle in the environment, and is produced in large quantity for industrial use (e.g., agriculture fertilizers and household cleaning products); $\mathrm{NH}_{3}$ at high concentrations (e.g., during occupational exposure or chemical accident) can cause lung injury and other detrimental health effects [55].

TNFa and Veh were administered by i.t. instillation in two separate groups of young C57BL6/J mice as described earlier [27], and cough responses to $\mathrm{NH}_{3}$ inhalation challenges were measured on days 2, 3, 6 and 7 after the TNFa or Veh treatment. Because the cough reflex is suppressed by general anesthesia, this study was carried out in awake mice. The methodology was described in details in a recent report [28]. Briefly, during the experiment, mice moved freely in a plexiglass recording chamber (volume $160 \mathrm{ml}$ ). To prevent $\mathrm{CO}_{2}$ accumulation and hyperthermia, room air was drawn through the chamber at a constant flow rate $(200 \mathrm{ml} / \mathrm{min})$ by a negative pressure. The pressure change in the chamber $\left(\mathrm{P}_{\text {cham }}\right)$, audio and video signals of the mouse movements were recorded simultaneously and used collectively for analyzing the cough frequency (Fig. 5A). Because breathing is inherently unstable in awake free-moving mice, the accuracy of the cough analysis was further verified by comparing with the changes of the intra-pleural pressure $\left(\mathrm{P}_{\mathrm{ip}}\right)$ (e.g., Fig. 5A), which was measured directly by surgically implanting the tip of a telemetry sensor in the intra-pleural space [28].

The action of cough recorded in these mice consisted three distinct but tightly connected phases as characterized by the synchronized changes in both $\mathrm{P}_{\text {cham }}$ and $\mathrm{P}_{\mathrm{ip}}$ : it was initiated by an inspiratory effort followed by a chest compression, and then a forced expiration that coincided with a weak but detectable cough sound. Expiratory reflex, similar to that described in other species [56,57], were also frequently found in awake mice; in comparison, the expiration reflex consisted only a chest compression, with no clear or significant preceding inspiratory effort, and followed by a forced expiration (Fig. 5B). In addition, $\sim 15 \%$ of the responses could not be easily distinguished between cough and expiration reflexes in our experiments [28]. Because both coughs and expiration reflexes are airway 
defense responses, they were pooled for data analysis in the evaluation of the overall cough responses in this study (Fig. 6).

In this study, the mouse was placed in the recording chamber for $>30$ min of adaptation period before each experiment. During the irritant gas inhalation challenge, ammonia $\left(\mathrm{NH}_{3}\right.$; $0.1 \%$ in air) was drawn into the chamber at the same flow rate as during baseline for 8 minutes; the cough frequency was analyzed for the 5-min baseline, 8-min challenge and 5min recovery in each animal. The cough frequency was near zero at the baseline (before the $\mathrm{NH}_{3}$ inhalation challenge) in both Veh- and $\mathrm{TNFa}$-treated mice, which did not change significantly after either Veh or TNFa treatment (Fig. 6). However, $48 \mathrm{~h}$ after the TNFa treatment, the cough frequency during the $\mathrm{NH}_{3}$ inhalation challenge was elevated to more than five folds of that before the TNFa treatment, and the enhanced cough responsiveness to the $\mathrm{NH}_{3}$ inhalation challenge persisted even after 7 days (Fig. 6). In sharp contrast, there was no significant change in the cough response to $\mathrm{NH}_{3}$ at any of these time points after the Veh treatment.

The cough reflex elicited by $\mathrm{NH}_{3}$ of was probably elicited by activation of C-fibers and/or rapidly adapting receptors (RARs) located in the lung and airways $[11,22,58]$ and/or tracheal cough receptors [40]. Indeed, using a single-fiber recording technique, we have shown that the $\mathrm{NH}_{3}(0.1 \%$ concentration $)$ inhalation challenge stimulated both these two types of vagal bronchopulmonary afferents in anesthetized mice (unpublished data). However, we cannot evaluate the relative role(s) of these different afferents in the $\mathrm{TNFa}$-induced increase in cough response to inhaled $\mathrm{NH}_{3}$ in this study.

$\mathrm{NH}_{3}$ has been shown to stimulate both TRPV1 and transient receptor potential ankyrine type 1 (TRPA1) receptors [59]. Both TRPV1 and TRPA1 receptors are ligand-gated non-selective cation channels [34], and known to play important roles in the inflammation-induced hypersensitivity of vagal bronchopulmonary afferents [11,12]. Our earlier studies have demonstrated that he same TNFa treatment induced pronounced airway inflammation and elevated sensitivities of both C-fibers and RARs in the lungs. Together, these results seem to suggest that the increased cough responses to $\mathrm{NH}_{3}$ was caused by the TNFa-induced hypersensitivity of these bronchopulmonary afferents.

\section{Conclusion}

These studies demonstrated that intra-tracheal instillation of TNFa induced pronounced airway inflammation as illustrated by infiltration of eosinophils and neutrophils and the release of inflammatory mediators and cytokines in the lung and airways. Coinciding with the time of these changes, the TNFa treatment induced a distinct increase in the Cap sensitivity in vagal pulmonary C-fibers and silent RARs. Furthermore, the increased sensitivity to Cap was also present in the isolated pulmonary sensory neurons, suggesting that the sensitizing effect was mediated primarily through a direct action of TNFa on these neurons. Indeed, the same TNFa treatment also induced a lingering ( $>7$ days) cough hyperresponsiveness to inhalation challenge of $\mathrm{NH}_{3}$ in awake mice, further illustrating the heightening sensitivity of these bronchopulmonary afferents. 
Stimulation of bronchopulmonary C-fiber afferents can also elicit bronchoconstriction and airway hypersecretion via the cholinergic reflex pathways [20,35]; intense stimulation can further generate neurogenic inflammation in the airways mediated through local axonal reflex mechanism [36,37]. Hence, when the excitability of C-fiber afferents is enhanced by endogenous TNFa, these airway reflex responses to a given stimulus is expected to be intensified. The finding of the TNFa-induced hypersensitivity of bronchopulmonary C-fiber afferents in these studies may explain, at least in part, the airway hyperresponsiveness and inflammation caused by Inhalation of TNFa in healthy humans [10].

Both the airway inflammation and the sensitizing effect on pulmonary sensory neurons caused by the TNFa treatment were abolished in the $\mathrm{TNF}^{-/}$mice. These results further suggested the involvement of TNFR receptors. We believe that the activation of TNFRs by $\mathrm{TNFa}$ may activate several signaling pathways, trigger chemotactic actions, and enhance the release of inflammatory mediators and cytokines in the airways. Together, these TNFRsmediated actions may upregulate the sensitivity and/or expression of TRPV1 in the bronchopulmonary sensory nerves. Although the mechanism(s) underlying the potentiating effect of TNFa on these vagal bronchopulmonary sensory nerves is still not fully understood, these studies have established the evidence of this sensitizing effect of TNFa in mice, which should facilitate further investigations of the potential involvements of certain TNFR-mediated signaling pathways in transgenic and knockout mouse models.

\section{Acknowledgments}

The authors thank Jeff Hong, Marcus Greer and Ashami Athukorala for their technical assistances. This study was supported in part by NIH grants AI123832, HL96914 and UL1TR001998.

\section{References}

1. Berry MA, Hargadon B, Shelley M, Parker D, Shaw DE, Green RH, et al. Evidence of a role of tumor necrosis factor alpha in refractory asthma. N Engl J Med. 2006; 354:697-708. [PubMed: 16481637]

2. Brightling C, Berry M, Amrani Y. Targeting TNF-alpha: a novel therapeutic approach for asthma. J Allergy Clin Immunol. 2008; 121:5-10. quiz 1-2. [PubMed: 18036647]

3. Heffler E, Berry M, Pavord ID. Tumor necrosis factor-alpha: a promising therapeutic target for asthma? BioDrugs. 2007; 21:345-9. [PubMed: 18020618]

4. Howarth PH, Babu KS, Arshad HS, Lau L, Buckley M, McConnell W, et al. Tumour necrosis factor (TNFalpha) as a novel therapeutic target in symptomatic corticosteroid dependent asthma. Thorax. 2005; 60:1012-8. [PubMed: 16166100]

5. Thomas PS. Tumour necrosis factor-alpha: the role of this multifunctional cytokine in asthma. Immunol Cell Biol. 2001; 79:132-40. [PubMed: 11264706]

6. Keatings VM, O'Connor BJ, Wright LG, Huston DP, Corrigan CJ, Barnes PJ. Late response to allergen is associated with increased concentrations of tumor necrosis factor-alpha and IL-5 in induced sputum. J Allergy Clin Immunol. 1997; 99:693-8. [PubMed: 9155837]

7. Matsunaga K, Yanagisawa S, Ichikawa T, Ueshima K, Akamatsu K, Hirano T, et al. Airway cytokine expression measured by means of protein array in exhaled breath condensate: correlation with physiologic properties in asthmatic patients. J Allergy Clin Immunol. 2006; 118:84-90. [PubMed: 16815142]

8. Gosset P, Tsicopoulos A, Wallaert B, Joseph M, Capron A, Tonnel AB. Tumor necrosis factor alpha and interleukin- 6 production by human mononuclear phagocytes from allergic asthmatics after IgEdependent stimulation. Am Rev Respir Dis. 1992; 146:768-74. [PubMed: 1519861] 
9. Cembrzynska-Nowak M, Szklarz E, Inglot AD, Teodorczyk-Injeyan JA. Elevated release of tumor necrosis factor-alpha and interferon-gamma by bronchoalveolar leukocytes from patients with bronchial asthma. Am Rev Respir Dis. 1993; 147:291-5. [PubMed: 8430950]

10. Thomas PS, Yates DH, Barnes PJ. Tumor necrosis factor-alpha increases airway responsiveness and sputum neutrophilia in normal human subjects. Am J Respir Crit Care Med. 1995; 152:76-80. [PubMed: 7599866]

11. Lee LY, Yu J. Sensory nerves in lung and airways. Compr Physiol. 2014; 4:287-324. [PubMed: 24692141]

12. Mazzone SB, Undem BJ. Vagal Afferent Innervation of the Airways in Health and Disease. Physiol Rev. 2016; 96:975-1024. [PubMed: 27279650]

13. Cunha FQ, Poole S, Lorenzetti BB, Ferreira SH. The pivotal role of tumour necrosis factor alpha in the development of inflammatory hyperalgesia. Br J Pharmacol. 1992; 107:660-4. [PubMed: 1472964]

14. Nicol GD, Lopshire JC, Pafford CM. Tumor necrosis factor enhances the capsaicin sensitivity of rat sensory neurons. J Neurosci. 1997; 17:975-82. [PubMed: 8994052]

15. Rozas P, Lazcano P, Pina R, Cho A, Terse A, Pertusa M, et al. Targeted overexpression of tumor necrosis factor-alpha increases cyclin-dependent kinase 5 activity and TRPV1-dependent Ca2+ influx in trigeminal neurons. Pain. 2016; 157:1346-62. [PubMed: 26894912]

16. Schaible HG, von Banchet GS, Boettger MK, Brauer R, Gajda M, Richter F, et al. The role of proinflammatory cytokines in the generation and maintenance of joint pain. Ann N Y Acad Sci. 2010; 1193:60-9. [PubMed: 20398009]

17. Constantin CE, Mair N, Sailer CA, Andratsch M, Xu ZZ, Blumer MJ, et al. Endogenous tumor necrosis factor alpha (TNFalpha) requires TNF receptor type 2 to generate heat hyperalgesia in a mouse cancer model. J Neurosci. 2008; 28:5072-81. [PubMed: 18463260]

18. Hensellek S, Brell P, Schaible HG, Brauer R, Segond von Banchet G. The cytokine TNFalpha increases the proportion of DRG neurones expressing the TRPV1 receptor via the TNFR1 receptor and ERK activation. Mol Cell Neurosci. 2007; 36:381-91. [PubMed: 17851089]

19. Jammes Y, Fornaris E, Mei N, Barrat E. Afferent and efferent components of the bronchial vagal branches in cats. J Auton Nerv Syst. 1982; 5:165-76. [PubMed: 7086068]

20. Coleridge JC, Coleridge HM. Afferent vagal C fibre innervation of the lungs and airways and its functional significance. Rev Physiol Biochem Pharmacol. 1984; 99:1-110. [PubMed: 6695127]

21. Nassenstein C, Taylor-Clark TE, Myers AC, Ru F, Nandigama R, Bettner W, et al. Phenotypic distinctions between neural crest and placodal derived vagal C-fibres in mouse lungs. J Physiol. 2010; 588:4769-83. [PubMed: 20937710]

22. Ho CY, Gu Q, Lin YS, Lee LY. Sensitivity of vagal afferent endings to chemical irritants in the rat lung. Respir Physiol. 2001; 127:113-24. [PubMed: 11504584]

23. Watanabe N, Horie S, Michael GJ, Keir S, Spina D, Page CP, et al. Immunohistochemical colocalization of transient receptor potential vanilloid (TRPV)1 and sensory neuropeptides in the guinea-pig respiratory system. Neuroscience. 2006; 141:1533-43. [PubMed: 16765524]

24. Groneberg DA, Niimi A, Dinh QT, Cosio B, Hew M, Fischer A, et al. Increased expression of transient receptor potential vanilloid-1 in airway nerves of chronic cough. Am J Respir Crit Care Med. 2004; 170:1276-80. [PubMed: 15447941]

25. Zhang G, Lin RL, Wiggers M, Snow DM, Lee LY. Altered expression of TRPV1 and sensitivity to capsaicin in pulmonary myelinated afferents following chronic airway inflammation in the rat. J Physiol. 2008; 586:5771-86. [PubMed: 18832423]

26. Lin RL, Gu Q, Lee LY. Hypersensitivity of vagal pulmonary afferents induced by tumor necrosis factor alpha in mice. Front Physiol. 2017; Accepted. doi: 10.3389/fphys.2017.00411

27. Lin RL, Lin YJ, Geer MJ, Kryscio R, Lee LY. Pulmonary chemoreflex responses are potentiated by tumor necrosis factor-alpha in mice. J Appl Physiol (1985). 2013; 114:1536-43. [PubMed: 23539315]

28. Zhang C, Lin RL, Hong J, Khosravi M, Lee LY. Cough and expiration reflexes elicited by inhaled irritant gases are intensified in ovalbumin-sensitized mice. Am J Physiol Regul Integr Comp Physiol. 2017; 312:R718-26. [PubMed: 28228416] 
29. Bradding P, Roberts JA, Britten KM, Montefort S, Djukanovic R, Mueller R, et al. Interleukin-4 -5, and -6 and tumor necrosis factor-alpha in normal and asthmatic airways: evidence for the human mast cell as a source of these cytokines. Am J Respir Cell Mol Biol. 1994; 10:471-80. [PubMed: 8179909]

30. Nakae S, Ho LH, Yu M, Monteforte R, Iikura M, Suto H, et al. Mast cell-derived TNF contributes to airway hyperreactivity, inflammation, and TH2 cytokine production in an asthma model in mice. J Allergy Clin Immunol. 2007; 120:48-55. [PubMed: 17482668]

31. Oyoshi MK, Bryce P, Goya S, Pichavant M, Umetsu DT, Oettgen HC, et al. TNF receptorassociated factor 1 expressed in resident lung cells is required for the development of allergic lung inflammation. J Immunol. 2008; 180:1878-85. [PubMed: 18209085]

32. Manfredi AA, Rovere-Querini P, Bottazzi B, Garlanda C, Mantovani A. Pentraxins, humoral innate immunity and tissue injury. Curr Opin Immunol. 2008; 20:538-44. [PubMed: 18579363]

33. Caterina MJ, Schumacher MA, Tominaga M, Rosen TA, Levine JD, Julius D. The capsaicin receptor: a heat-activated ion channel in the pain pathway. Nature. 1997; 389:816-24. [PubMed: 9349813]

34. Nilius B, Owsianik G, Voets T, Peters JA. Transient receptor potential cation channels in disease. Physiol Rev. 2007; 87:165-217. [PubMed: 17237345]

35. Lee LY, Pisarri TE. Afferent properties and reflex functions of bronchopulmonary C-fibers. Respir Physiol. 2001; 125:47-65. [PubMed: 11240152]

36. Baluk P, Nadel JA, McDonald DM. Substance P-immunoreactive sensory axons in the rat respiratory tract: a quantitative study of their distribution and role in neurogenic inflammation. $\mathrm{J}$ Comp Neurol. 1992; 319:586-98. [PubMed: 1377714]

37. De Swert KO, Joos GF. Extending the understanding of sensory neuropeptides. Eur J Pharmacol. 2006; 533:171-81. [PubMed: 16464447]

38. Lin S, Li H, Xu L, Moldoveanu B, Guardiola J, Yu J. Arachidonic acid products in airway nociceptor activation during acute lung injury. Exp Physiol. 2011; 96:966-76. [PubMed: 21622966]

39. Widdicombe JG. Receptors in the trachea and bronchi of the cat. J Physiol. 1954; 123:71-104. [PubMed: 13131247]

40. Canning BJ, Mazzone SB, Meeker SN, Mori N, Reynolds SM, Undem BJ. Identification of the tracheal and laryngeal afferent neurones mediating cough in anaesthetized guinea-pigs. J Physiol. 2004; 557:543-58. [PubMed: 15004208]

41. Grynkiewicz G, Poenie M, Tsien RY. A new generation of Ca2+ indicators with greatly improved fluorescence properties. J Biol Chem. 1985; 260:3440-50. [PubMed: 3838314]

42. Kwong K, Lee LY. PGE(2) sensitizes cultured pulmonary vagal sensory neurons to chemical and electrical stimuli. J Appl Physiol (1985). 2002; 93:1419-28. [PubMed: 12235043]

43. Gu Q, Kwong K, Lee LY. Ca2+ transient evoked by chemical stimulation is enhanced by PGE2 in vagal sensory neurons: role of cAMP/PKA signaling pathway. J Neurophysiol. 2003; 89:1985-93. [PubMed: 12612039]

44. Hu Y, Gu Q, Lin RL, Kryscio R, Lee LY. Calcium transient evoked by TRPV1 activators is enhanced by tumor necrosis factor-\{alpha\} in rat pulmonary sensory neurons. Am J Physiol Lung Cell Mol Physiol. 2010; 299:L483-92. [PubMed: 20639352]

45. Brockhaus M, Schoenfeld HJ, Schlaeger EJ, Hunziker W, Lesslauer W, Loetscher H. Identification of two types of tumor necrosis factor receptors on human cell lines by monoclonal antibodies. Proc Natl Acad Sci U S A. 1990; 87:3127-31. [PubMed: 2158104]

46. Baud V, Karin M. Signal transduction by tumor necrosis factor and its relatives. Trends Cell Biol. 2001; 11:372-7. [PubMed: 11514191]

47. Utreras E, Futatsugi A, Rudrabhatla P, Keller J, Iadarola MJ, Pant HC, et al. Tumor necrosis factoralpha regulates cyclin-dependent kinase 5 activity during pain signaling through transcriptional activation of p35. J Biol Chem. 2009; 284:2275-84. [PubMed: 19049962]

48. Furukawa K, Mattson MP. The transcription factor NF-kappaB mediates increases in calcium currents and decreases in NMDA- and AMPA/kainate-induced currents induced by tumor necrosis factor-alpha in hippocampal neurons. J Neurochem. 1998; 70:1876-86. [PubMed: 9572271] 
49. Barbin G, Roisin MP, Zalc B. Tumor necrosis factor alpha activates the phosphorylation of ERK, SAPK/JNK, and P38 kinase in primary cultures of neurons. Neurochem Res. 2001; 26:107-12. [PubMed: 11478736]

50. Ji RR, Samad TA, Jin SX, Schmoll R, Woolf CJ. p38 MAPK activation by NGF in primary sensory neurons after inflammation increases TRPV1 levels and maintains heat hyperalgesia. Neuron. 2002; 36:57-68. [PubMed: 12367506]

51. Robitaille R, Garcia ML, Kaczorowski GJ, Charlton MP. Functional colocalization of calcium and calcium-gated potassium channels in control of transmitter release. Neuron. 1993; 11:645-55. [PubMed: 7691106]

52. Gover TD, Moreira TH, Weinreich D. Role of calcium in regulating primary sensory neuronal excitability. Handb Exp Pharmacol. 2009:563-87. [PubMed: 19655118]

53. Ghosh A, Greenberg ME. Calcium signaling in neurons: molecular mechanisms and cellular consequences. Science. 1995; 268:239-47. [PubMed: 7716515]

54. Simpson PB, Challiss RA, Nahorski SR. Neuronal Ca2+ stores: activation and function. Trends Neurosci. 1995; 18:299-306. [PubMed: 7571010]

55. Department of Health And Human Services PHS. , editor. Division-of-Toxicology. Public Health Statement: Ammonia (CAS\#: 7664-41-7). Atlanta, GA: Agency For Toxic Substances And Disease Registry; 2004.

56. Tatar M, Hanacek J, Widdicombe J. The expiration reflex from the trachea and bronchi. Eur Respir J. 2008; 31:385-90. [PubMed: 17959638]

57. Widdicombe J, Fontana G. Cough: what's in a name? Eur Respir J. 2006; 28:10-5. [PubMed: 16816346]

58. Canning BJ, Mori N, Mazzone SB. Vagal afferent nerves regulating the cough reflex. Respir Physiol Neurobiol. 2006; 152:223-42. [PubMed: 16740418]

59. Dhaka A, Uzzell V, Dubin AE, Mathur J, Petrus M, Bandell M, et al. TRPV1 is activated by both acidic and basic pH. J Neurosci. 2009; 29:153-8. [PubMed: 19129393] 


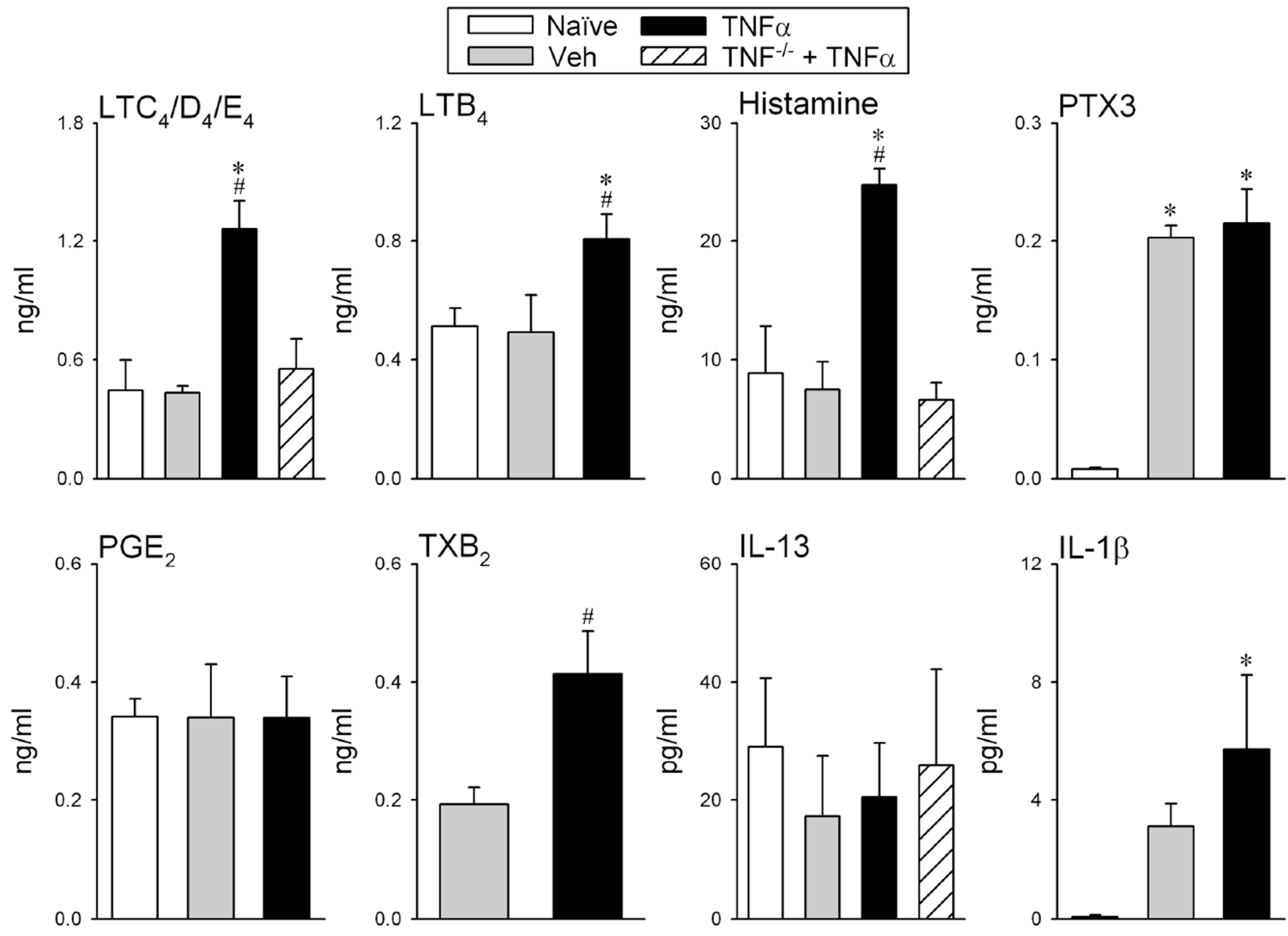

Fig. 1.

Effect of TNFa treatment on inflammatory mediators in bronchoalveolar lavage fluid (BALF). Naïve group (open bars; WT mice receiving no surgery or treatment); Veh group (shaded bars; WT mice pretreated with vehicle PBS); TNFa group (closed bars; WT mice pretreated with $\mathrm{TNFa}$ ); $\mathrm{TNF}^{-/-}+\mathrm{TNFa}$ group (hatched bars; $\mathrm{TNF}^{-/-}$mice pretreated with $\mathrm{TNFa}$ ). BALF was collected at 24 hours after the pretreatment of TNFa or vehicle. $\mathrm{LTB}_{4}$ and $\mathrm{LTC}_{4} / \mathrm{D}_{4} / \mathrm{E}_{4}$ : leukotrienes $\mathrm{B}_{4}$ and $\mathrm{C}_{4} / \mathrm{D}_{4} / \mathrm{E}_{4}$, respectively; PTX3: pentraxin 3; $\mathrm{PGE}_{2}$ : prostaglandin $\mathrm{E}_{2} ; \mathrm{TXB}_{2}$, thromboxane $\mathrm{B}_{2} ; \mathrm{IL}-13$ and IL-1 $\beta$ : interleukins 13 and 1 beta, respectively. Each data point represents means \pm SEM of the measurements; the total number of mice used in these groups varied: $n=10,15,15$ and 5 in naïve, Veh, TNFa, and $\mathrm{TNF}^{-/}+\mathrm{TNFa}$ groups, respectively. Thus, some tests (e.g., $\mathrm{LTB}_{4}, \mathrm{IL}-1 \beta$ ) were only performed in two or three groups of mice. *, significantly different from naïve group $(P<$ $0.05)$. \#, significantly different from Veh group $(P<0.05)$. (Modified from reference [27]) 


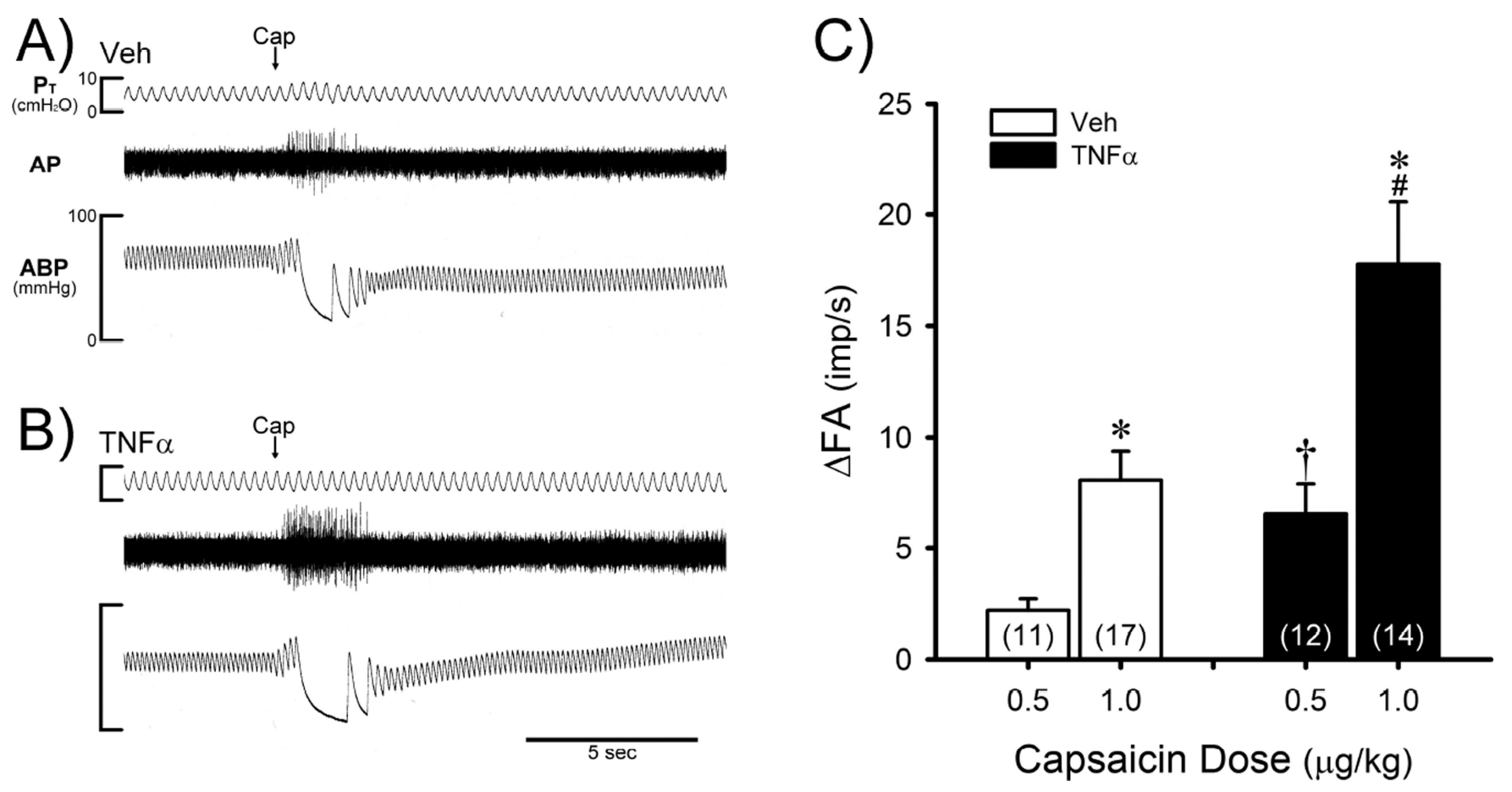

Fig. 2.

A) Experimental records illustrating the effect of TNFa on the responses of pulmonary $\mathrm{C}$ fibers to capsaicin in anesthetized, open-chest and artificially ventilated mice. Vehicle (Veh; $0.03 \mathrm{ml}$ of PBS$)$ and TNFa $(10 \mu \mathrm{g} / \mathrm{ml}, 0.03 \mathrm{ml})$ were administered by intratracheal instillation into the lungs of Veh and TNFa mice (weights: $27.8 \mathrm{~g} \& 25.9 \mathrm{~g}$ ), respectively, ? $24 \mathrm{~h}$ earlier. Arrows were added to mark the time when capsaicin (Cap; $1.0 \mu \mathrm{g} / \mathrm{kg}$ ) was injected intravenously as a bolus. Both receptor locations were in the right lung. $\mathrm{P}_{\mathrm{T}}$, tracheal pressure; AP, action potential; ABP, arterial blood pressure. B) Group data of pulmonary C fiber responses to the Cap injection $\sim 24 \mathrm{~h}$ after the Veh (open bars) and TNFa (closed bars) treatments.. $\triangle \mathrm{FA}$ : the increase in fiber activity (FA; impulses/s) from baseline (averaged over the 10 -s period preceding the injection) to the peak response (averaged over 2 -s duration) within the first $5 \mathrm{~s}$ after the injection. The number in each bar represents the number of fibers studied under that condition. * significantly different from the low dose of Cap (0.5 $\mu \mathrm{g} / \mathrm{kg})(P<0.05)$. \# significantly different from the Veh group $(P<0.05)$. Data are means \pm SEM. (Modified from reference [26]) 
A) Veh

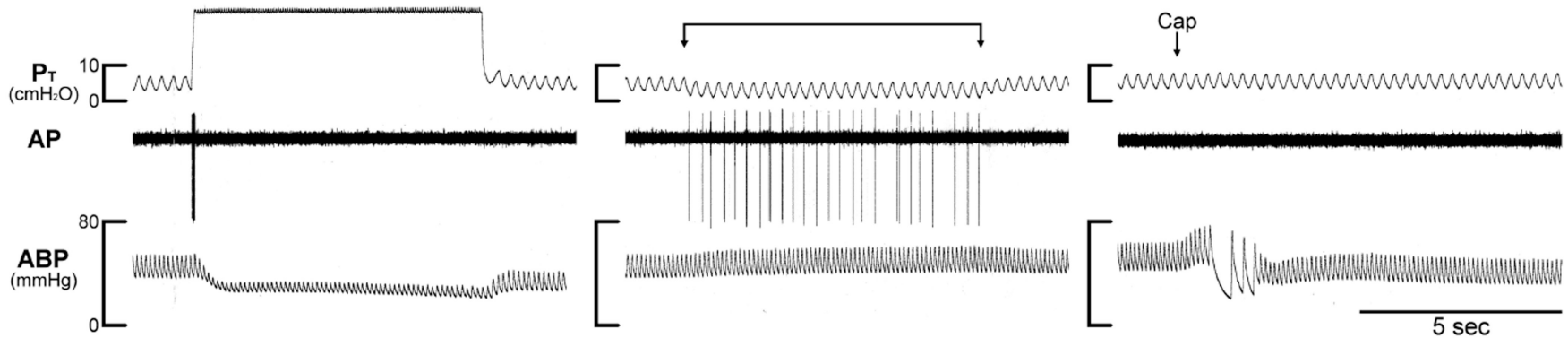

\section{B) $\mathrm{TNF}_{\alpha}$}
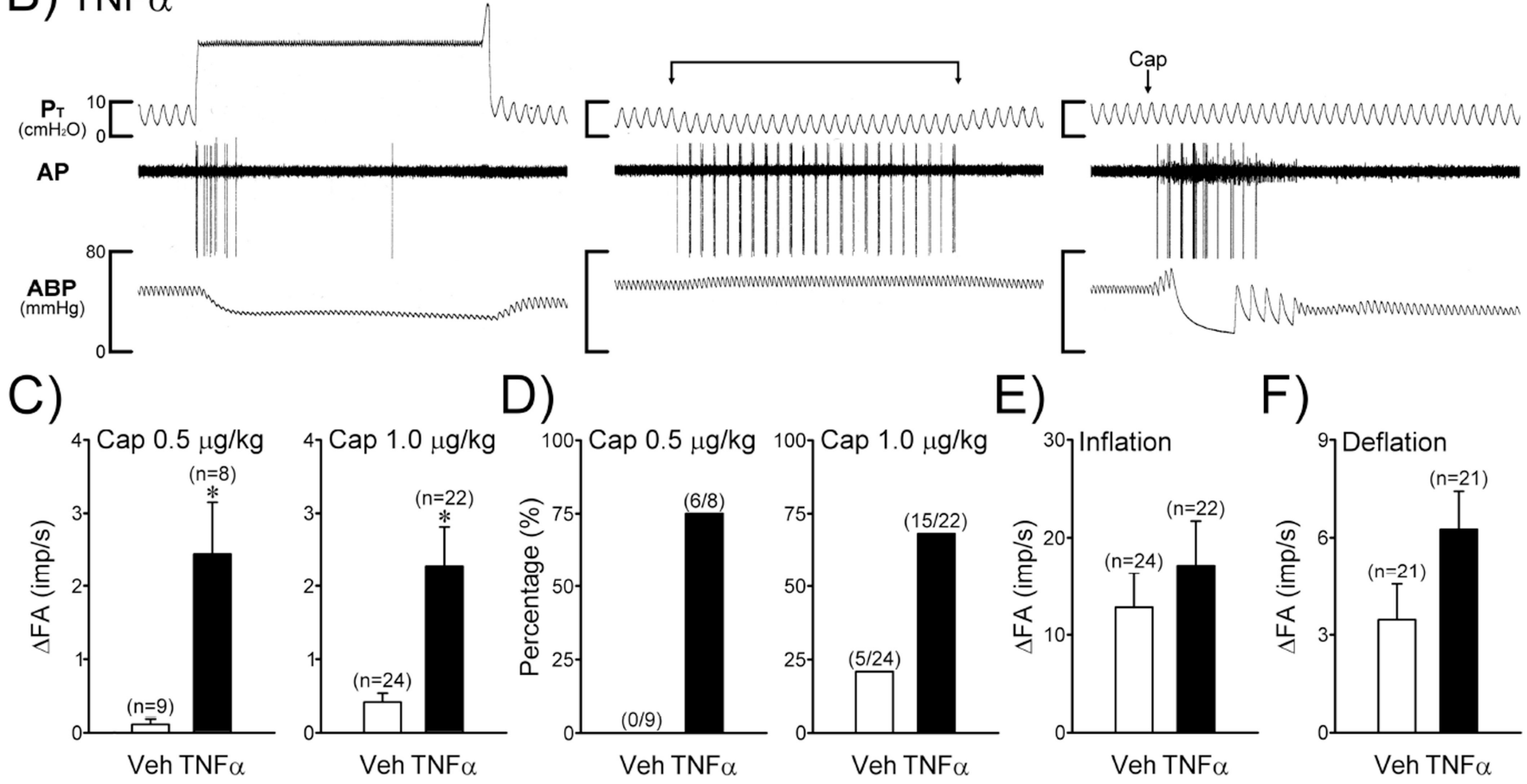

F)

Fig. 3.

A) \& B): Experimental records illustrating the effect of TNFa on the responses of silent RARs to capsaicin, inflation and deflation of the lung in two anesthetized, open-chest and artificially ventilated mice. A) Veh (0.03 $\mathrm{ml}$ of PBS) and B) TNFa (10 $\mu \mathrm{g} / \mathrm{ml}, 0.03 \mathrm{ml})$ were administered $\sim 24 \mathrm{~h}$ earlier by intratracheal instillation into the lungs of Veh and TNFa mice (weights: $31.8 \mathrm{~g} \& 25.9 \mathrm{~g}$ ), respectively. In both A) and B), left panels: responses to constant pressure $\left(30 \mathrm{cmH}_{2} \mathrm{O}\right)$ hyperinflations of the lungs for $8 \mathrm{~s}$ when the ventilator was turned off; middle panels: responses to lung deflations when the expiratory line of the ventilator was exposed to atmospheric pressure; right panels: responses to intravenous bolus injections of capsaicin $(1.0 \mu \mathrm{g} / \mathrm{kg})$ at arrows. Both receptor locations were in the right lung. From C) to F): group data of silent RARs after treatments with Veh (open bars) and TNFa (closed bars). C): responses to Cap injections $(0.5 \& 1.0 \mu \mathrm{g} / \mathrm{kg})$; see the legend of Fig. $2 \mathrm{~B}$ for explanations. D): percentages of silent RARs that exhibited Cap sensitivity $(\Delta \mathrm{FA}>1.0 \mathrm{imp} / \mathrm{s}$ after Cap injection). E): response to lung hyperinflation $\left(\mathrm{P}_{\mathrm{T}}=30 \mathrm{cmH}_{2} \mathrm{O}\right) ; \Delta \mathrm{FA}$ : the difference in FA between the first second of lung inflation and the baseline (averaged over $10 \mathrm{~s}) . \mathrm{F})$ : response to lung deflation; $\triangle \mathrm{FA}$ : the difference between the FA averaged over the 
8-s duration of deflation and the baseline (averaged over $10 \mathrm{~s}$ ). * significantly different from the Veh group $(P<0.05)$. (Modified from reference [26]) 

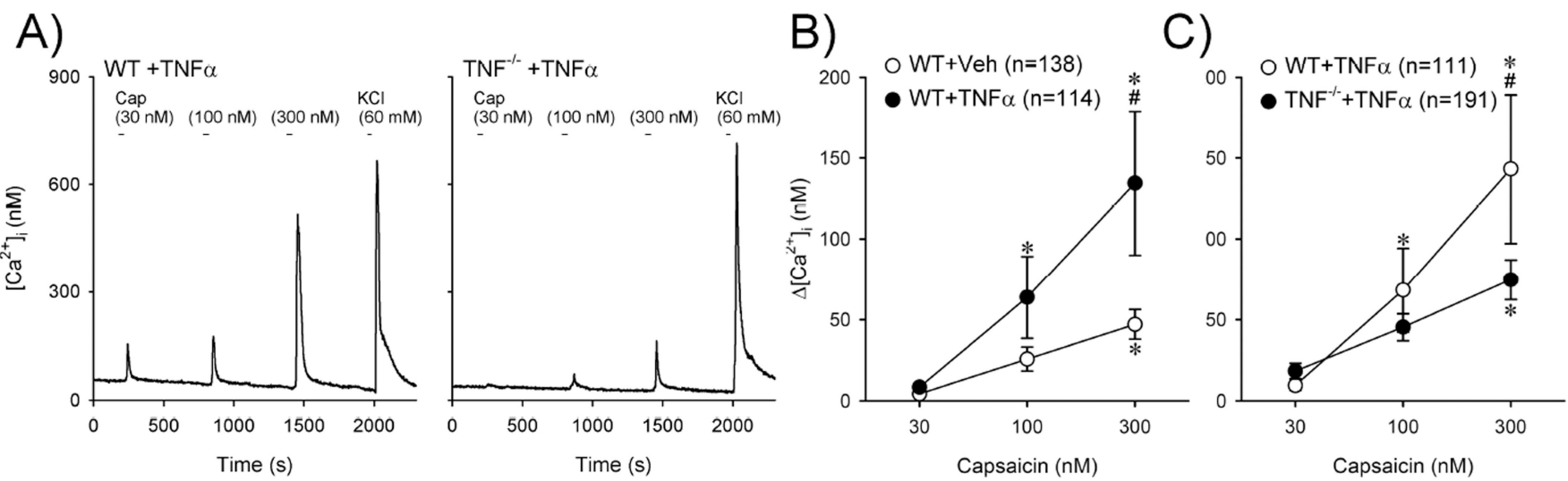

Fig. 4.

A) Representative experimental records illustrating the change in $\left[\mathrm{Ca}^{2+}\right]_{\mathrm{i}}$ evoked by increasing concentrations of capsaicin in vagal pulmonary sensory neurons. Left panel: a pulmonary neuron (diameter: $24 \mu \mathrm{m}$ ) isolated from a wild-type (WT) mouse; Right panel: a pulmonary neuron (diameter: $22 \mu \mathrm{m}$ ) isolated from a TNF-receptor double homozygous mutant (TNF-/-) mouse. Both WT and $\mathrm{TNF}^{-/-}$neurons had been incubated with TNFa (50 $\mathrm{ng} / \mathrm{ml}$ in culture medium) for $\sim 24 \mathrm{~h}$. Cap was applied for $30 \mathrm{~s}$ each, and $\mathrm{KCl}$ solution (60 $\mathrm{mM}, 20 \mathrm{~s}$ ) was applied to test cell vitality at the end of each experiment. B) Group data showing a comparison of the responses of $\left[\mathrm{Ca}^{2+}\right]_{i}$ to increasing concentrations of Cap between Veh- and TNFa-treated neurons isolated from wild-type (WT) mice.. C) Group data illustrating the effect of TNFa treatment on the $\left[\mathrm{Ca}^{2+}\right]_{\mathrm{i}}$ responses to increasing concentrations of Cap in neurons isolated from WT and $\mathrm{TNF}^{-/-}$mice. In both B) \& $\mathrm{C}$ ), *: significantly different from the corresponding response to $30 \mathrm{nM}$ capsaicin $(P<0.05)$. \# in B): significantly different from the corresponding data in Veh- treated neurons $(P<0.05)$; in C): significantly different from the corresponding data in $\mathrm{TNF}^{-/-}$neurons $(P<0.05)$. Data are mean \pm SEM. (Modified from reference [26]) 

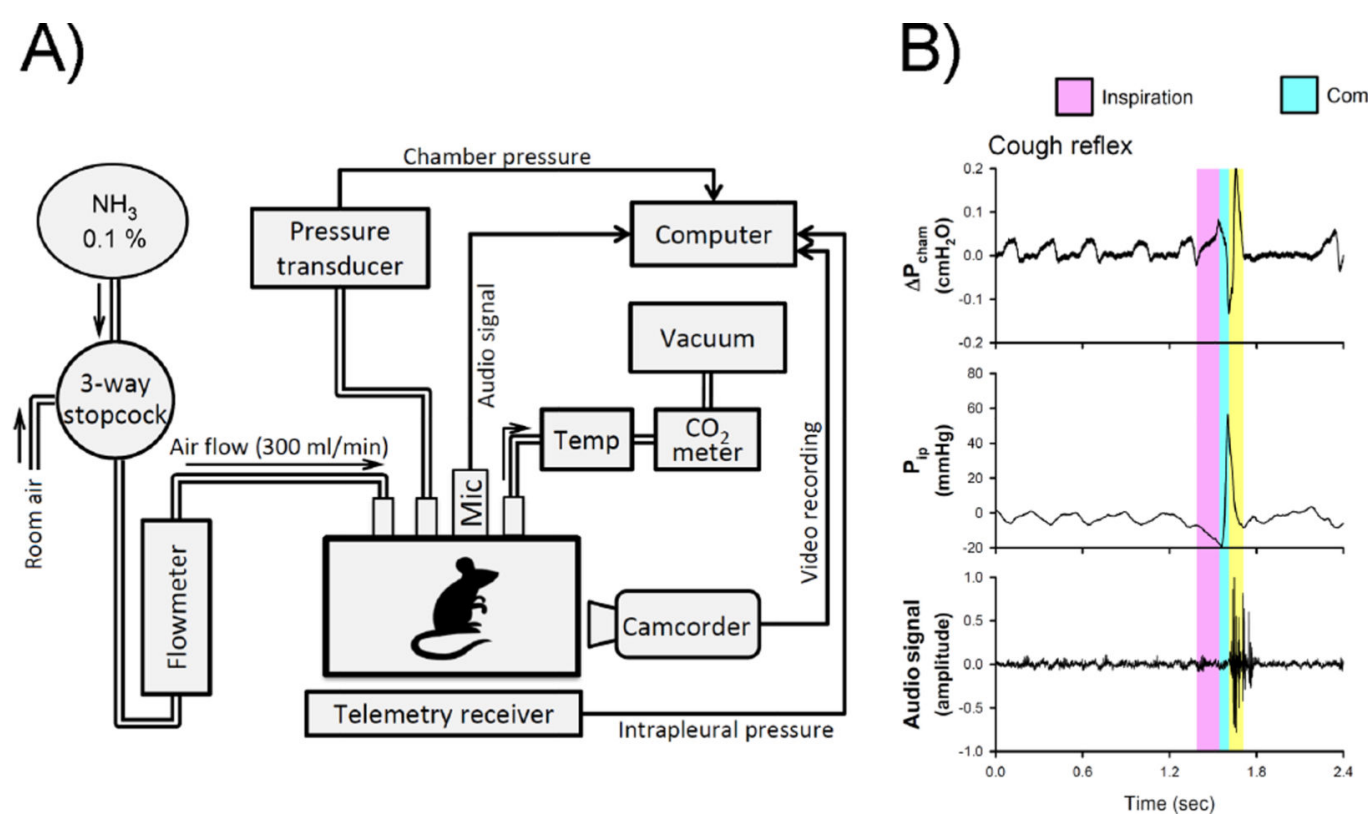

Compression $\square$ Expiration

Fig. 5 .

A): Schematic diagram of the experimental set-up. Mic: microphone for recording audio signal; Temp: air temperature in the chamber. B) Representative experimental records illustrating the characteristic features of pressure changes and the audio signal generated by a single cough (Left) and a single expiration reflex $($ Right $)$ in an awake mouse. $\mathrm{P}_{\text {cham }}$ : pressure inside the chamber; $\mathrm{P}_{\mathrm{ip}}$ : intra-pleural pressure recorded via the telemetry sensor. (Modified from reference [28]) 


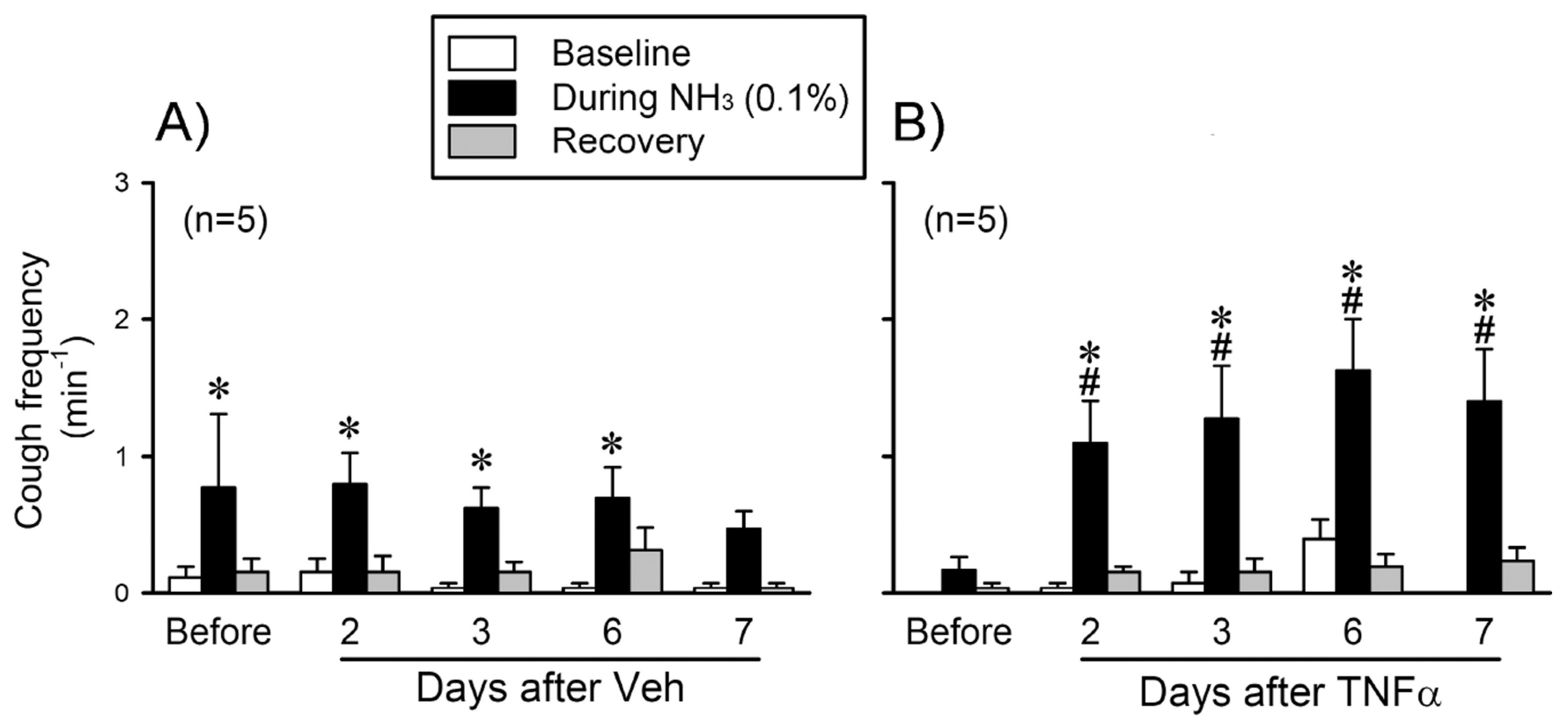

Fig. 6.

Effects of A) Vehicle (Veh, $0.03 \mathrm{ml}$ of PBS; n=5) and B) TNFa (10 $\mu \mathrm{g} / \mathrm{ml}, 0.03 \mathrm{ml}$; $\mathrm{n=5}$ ) treatments on the cough response to inhalation challenge of $\mathrm{NH}_{3}(0.1 \%)$ in awake mice at different time points after the treatment. The cough frequency count included both cough and expiration reflex. Data (means \pm SEM) represent the group responses averaged over the 5-, 8- and 5-min durations of "Baseline""During $\mathrm{NH}_{3}$ " and "Recovery", respectively. *, significantly $(P<0.05)$ different from the baseline data (open bars). \#, significantly $(P<$ 0.05 ) different from the corresponding data obtained before the Veh or TNFa treatment. 